\title{
Banana Flower-Insect Interaction: Alpha-Pinene as Potential Attractant for the Insect Vector of Banana Blood Disease
}

\author{
Masriany Masriany ${ }^{1,3}$, Rizkita R Esyanti ${ }^{2,3}$, Fenny M Dwivany ${ }^{2,3}$, Tjandra Anggraen $^{i^{*}}$ \\ ${ }^{1}$ Biological program study, Faculty of Science and Technology, Universitas Islam Negeri Alauddin Makassar, Makassar, Indonesia \\ ${ }^{2}$ Bali International Research Center for Banana, Universitas Udayana Bukit Jimbaran, Badung, Bali, Indonesia \\ ${ }^{3}$ School of Life Sciences and Technology, Institut Teknologi Bandung, Bandung, Indonesia
}

\section{ARTICLE INFO}

Article history:

Received February 10, 2017

Received in revised form September 20, 2019

Accepted September 30, 2019

\section{KEYWORDS:}

Volatile organic compounds (VOC),

plant-insect interaction,

insect vector,

attractant,

food security

\begin{abstract}
Volatile metabolites are produced by plants for self-defense and as communication mediators with the environment. Terpenes are volatiles emitted as odorant cues for herbivores and microorganisms. This study was aimed to investigate volatile metabolites produced by banana flowers that attract insect vectors of BBD. The volatile metabolites from banana flowers were extracted by headspace-solid phase microextraction (HS-SPME) and identified by gas chromatography-mass spectrometry (GC-MS). It was apparent that the concentrations of the metabolite alpha-pinene gradually increased from the first to the the third stage. Comparison of metabolites produced by symptomatic banana male flowers for BBD infection with non-symptomatic ones showed that the concentration of alpha-pinene was higher in symptomatic male flowers. In addition, preference for alpha-pinene was tested on three insect vector species (Rhodesiella bhutanensis, Drosophila sp., and Musca sp.), analyzed by M. Anova $\mathrm{p}<0.001, \mathrm{~F}_{(1.5)}=12.539$ and Duncan test. Results showed that the insect vectors were mostly attracted to $20 \mu$ l volume of alpha-pinene compared to the other volumes and that alpha-pinene functioned as an attractant to these insects. This research is important for the formulation of attractants for insect vectors of BBD to control transmission of banana blood disease.
\end{abstract}

\section{Introduction}

Volatile secondary metabolites produced by plants function as self-defense as well as media for communication between plants and their environment. Terpenoids are one type of secondary metabolites that are volatile (Junker and Bluthgen, 2010; Rodriguezcampos et al. 2012). Citrus fruits contain volatile substance limonene from the monoterpene group that can affect the interaction between plants, insects, and microorganisms. Nectar feeding insects visit flowers because they are attracted to the aroma of the flowers of the host plant (Bruce et al. 2005; Borghi and Fernie 2017). The floral aroma is a complex mixture of several volatile compounds that have different synthesis pathways and that have different effects on the insect's behavior (Pischerky and Gershenzon 2002). The flower's release of volatile compounds may act as an attractant, deterrent, or repellent for herbivorous

\footnotetext{
* Corresponding Author

E-mail Address: tjandra@sith.itb.ac.id

insects and the type of volatile compounds may affect their flower visiting frequency.

Mairawita et al. (2012) reported that banana plants infected with Blood Disease Bacterium (BDB) had a higher diversity of insects visiting the flowers compared to healthy ones. The initial symptoms of BDB attack on banana plants first occur in male flowers, in the form of discoloration of the male flowers, which then spread to other organs (Eden-Green 1994). In banana plants, flower-visiting insects are associated with blood diseases. Drosophila sp. has a potential to be a vector of blood disease in banana plants (Sahetapi 2013). Erionota thrax was suspected as a BDB vector because $\mathrm{BDB}$ was isolated from the insect's tissue (Suharjo et al. 2006). Masriany (unpublished data) reported that banana flower-visiting insects Rhodesiella bhutanensis and Drosophila sp. (Diptera) contained BDB.

Since 2005 most areas of Indonesia have already been infested with banana blood disease (Supriadi 2005; Hermanto 2011). The distribution of this pathogen is highly associated with the role of flower visiting insects as vector of BDB. This study analyzed the profiles of volatile compounds in banana flowers 
that might attract banana flower visiting insects. In this study, the volatile metabolites of banana flowers were compared between BDB infected flowers with noninfected ones at various banana flower developmental stages using GC-MS and the volatile compound that was suspected to act as an attractant was tested on three banana flower visiting insects, $R$. bhutanensis, Drosophila sp., and Musca sp.

\section{Materials and Methods}

\subsection{Sample Collection and GC-MS Analysis}

The collection of banana flowers was conducted at the banana plantation in the Experimental Garden of Tropical Fruit Research Institute (Balitbu-Tropika) in Subang. Banana flowers collected were: 1. Female flowers, to investigate the profile of banana flowers at the stage of inflorescence based on the opening phase of the flowers; 2. Male flowers infected with BDB and healthy male flowers. Each of the treatments was repeated by three time replication.

The extraction and identification of the banana flower volatiles was done by a modification of solid phase microextraction-headspace (SPME-HS/GCMS) method described by Rodriguez-Campos et al. (2012). Banana flowers (20 g) were placed inside $25 \mathrm{ml}$ jars (Sigma Aldrich), which then extracted by heating at $40^{\circ} \mathrm{C}$ for 30 minutes. The Fiber used was 50/30 $\mu \mathrm{m}$ DVB/CAR/PDMS (divinylbenzene/carboxen/ polydimethylsiloxane) obtained from Supelco (Sigma-Aldrich, Bellefonte, PA, USA). The fiber was injected directly into Hewlett Packard 6890 devices (Agilent Technologies Inc., Santa Clara, USA), Gas Chromatograph-Mass Spectrometer (GC-MS), and left for 15 minutes to maximize the distribution of volatile compounds. The device was programmed with splitless mode with the intention of all volatile compounds from the sample could be analyzed. The metabolite compounds were separated by using an Innowax capillary column $(60 \mathrm{~m} 0.25 \mathrm{~mm}$ id $0.25 \mathrm{~lm}$ film thickness) with helium as the carrier gas, flow rate: $0.7 \mathrm{ml} \mathrm{min-1.} \mathrm{The} \mathrm{oven} \mathrm{temperature} \mathrm{was} \mathrm{set} \mathrm{from}$ 40 to $200^{\circ} \mathrm{C}$ and the total GC working time was 35 minutes. Transfer MS was at $260^{\circ} \mathrm{C}$, ionization energy was $70 \mathrm{eV}$, and the mass range is $50-550 \mathrm{~m}$. The GCMS results were analyzed with Multivariate-Anova followed with Principal Component Analysis using Minitab 18.

\subsection{Insect Preference Assay for the Pure Metabolite}

Insects used for the preference assay were $R$. bhutanensis, Drosophila sp., and Musca domestica. $M$. domestica was reared in a box measuring $30 \times 30 \times 30$ $\mathrm{cm}$, the rearing method was adopted from (Kustiati et al. 2016). D. melanogaster was reared in glass bottles containing banana medium as feed. $R$. bhutanensis was captured from a banana garden, acclimatized in the Entomology Laboratory for two hours and then used in the preference assay. The preference assay was performed using a Y-olfactometer made of glass with each arm measuring $30 \mathrm{~cm}$ and a center tube with a diameter of $5 \mathrm{~cm}$ and a height of $7 \mathrm{~cm}$. The preference assay used was as described by Kogel et al. (1999), 30 insects were released into one tube at the end of the arm, filter paper with a certain volume of volatile substance alpha-pinene was placed inside the end of the second tube, and at the end the third tube was placed filter paper with ethanol as a negative control. The insects were first given 30 minutes to adapt to the olfactometer conditions, then after 15 minutes the number of insects that chose alpha-pinene and ethanol were counted. These observations were made up to six times, with 15 min intervals and the tests were performed with five repetitions. After each test, the olfactometer was washed with acetone and then dried. The volatile metabolite suspected to be a marker for BDB infested banana flowers was tested on the insects using the pure compound. Statistical analysis were conducted based on Multivariate- Anova and Duncan tests at $\alpha 0.01$.

\section{Results}

\subsection{Profiling of Volatile Metabolites from Banana Flowers}

The results of the GC-MS analysis of banana volatile metabolites showed several main peaks e.g. alpha-pinene, beta-pinene, decamethyl tetrasiloxane, limonene, undecane, and nonadecane (Figure 1).

The banana volatile metabolites were divided into 4 groups: 1 . Fatty acid derivatives, 2 . Terpenoids, 3. Benzenoids, and 4. Others (Table 1). The group with the largest area in the chromatogram was the Terpenoids.

\subsection{Comparison of Volatile Metabolites from Different Developmental Stages of the Female Banana Flower}

The formation of flowers on banana plants is divided into two main phases namely the early phase and the final phase. The early phase is the phase of the blooming of the female flowers, before the banana fruit is formed. This early phase consists of five stages (depending on cultivars). In this research, the banana flowers were analyzed at three main stages, namely stage 1 , stage 2 , and stage 3 (Figure $2 \mathrm{a}$ ). The division of the inflorescence into these stages is based on the time the rows of flowers bloom. In stage 1 , the first 


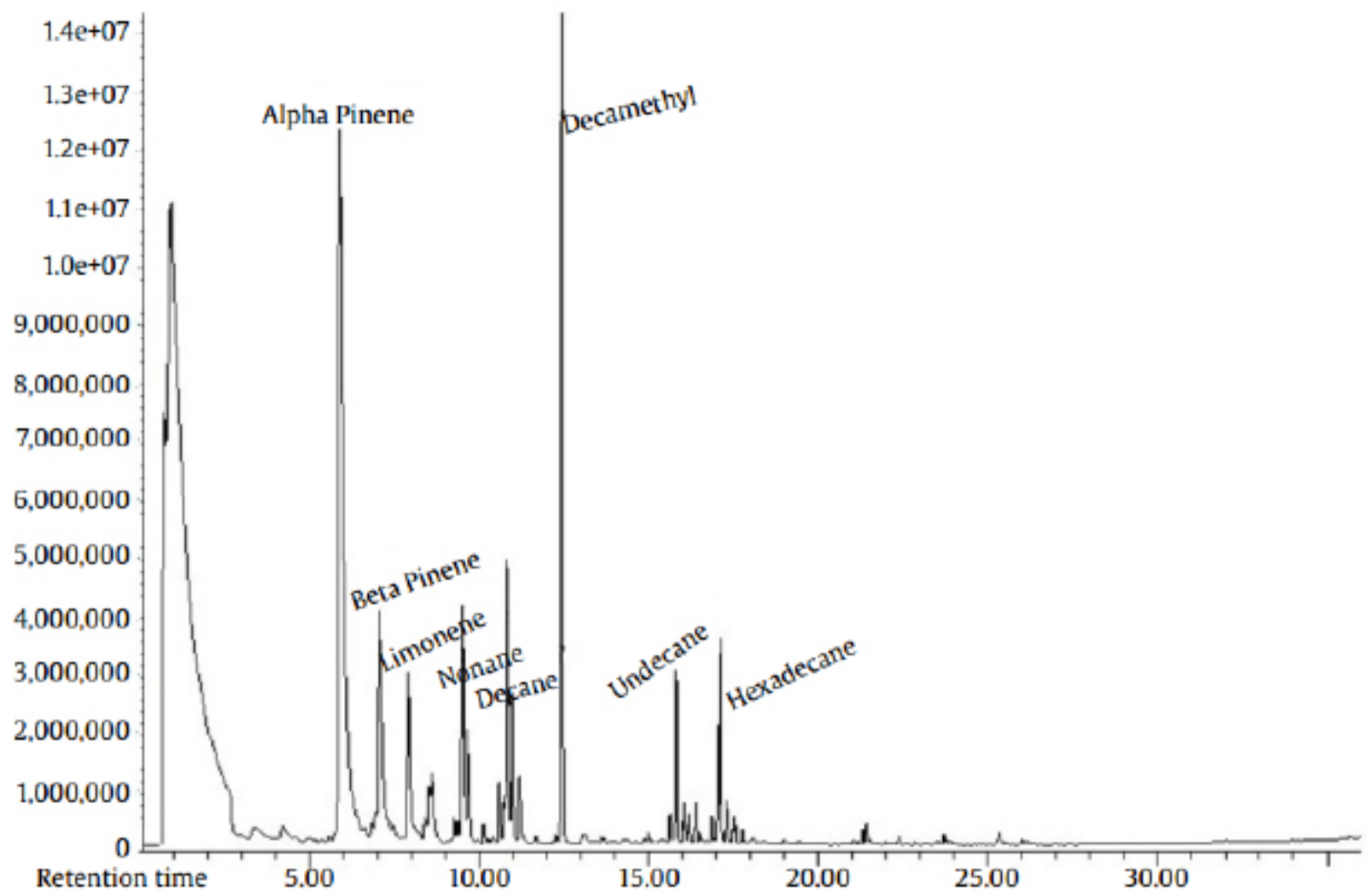

Figure 1. Chromatogram of banana flower volatile metabolite

Table 1. Volatile metabolites profile of the banana flower

\begin{tabular}{ccll}
\hline Retention time (minutes) & Area (\%) & Compounds & CAS No. \\
10,801 & 2.0651 & Fatty acid derivatives & $000124-18-5$ \\
10,963 & 1.0406 & Decane & $002980-69-0$ \\
15,801 & 0.9884 & Undecane & $000629-59-4$ \\
16,025 & 0.2408 & Tetradecane & $000629-62-9$ \\
16,175 & 0.2078 & Pentadecane & $000112-95-8$ \\
10,562 & 0.4565 & Eicosane & $004282-42-2$ \\
16,262 & 0.0265 & Nonane & $000630-02-4$ \\
16,848 & 0.1642 & Octacosane & $013187-99-0$ \\
17,286 & 0.3424 & Dodecane & $000638-36-8$ \\
22,380 & 0.0572 & Hexadecane & $000629-92-5$ \\
& & Nonadecane \\
5,914 & 14.0687 & Terpenoids & \\
6,805 & 0.2643 & Alpha.-Pinene & $007785-70-8$ \\
7,058 & 3.2906 & Trans-Pinane & $006876-13-7$ \\
8,589 & 0.8436 & Beta.-Pinene & $000127-91-3$ \\
& & Limonene & $000138-86-3$ \\
8,514 & 0.44 & Benzenoids & \\
& & Benzene & $000100-66-3$ \\
6,931 & 0.2267 & Others & \\
12,417 & 4.7375 & Octene & $062960-77-4$ \\
13,058 & 0.1132 & Decamethyl & $000541-02-6$ \\
13,131 & 0.1023 & Naphthalene & $000091-20-3$ \\
7,888 & 2.1179 & 1H-Indene, 1-methylene- & $002471-84-3$ \\
19,769 & 0.0265 & Octamethyl & $000556-67-2$ \\
& & Pteridinone, 2-amino- & $002236-60-4$ \\
\hline
\end{tabular}


row of flowers has bloomed, in stage 2 the first and the second rows of flowers are open and in stage 3 the first, second and third rows of flowers are open. Analysis of volatile metabolites in the development of female flowers showed discrimination of volatile compounds at each stage of the inflorescence (Figure 2b). Stage 1 was dominated by Hexadecane, Decane, and Undecane, stage 2 more dominated with Nonadecane, and stage 3 contained more limonene, beta-pinene, and alpha-pinene (Figure $2 \mathrm{c}$ ). Volatile metabolite analysis was performed only from the first stage to the third stage based on the highest insect visitation rate to the banana flowers (Masriany, unpublished data).

The final phase is the blooming of the male flowers that occurs after all fruits until the last comb were formed. Since banana plants are susceptible to BDB infestations at this final stage, comparative analysis of metabolites between healthy and symptomatic flowers were done on male flowers.

\subsection{Comparison of Volatile Metabolites from BDB Infected and Healthy Banana Male Flowers}

Volatile metabolite analysis of healthy (nonsymptomatic) and BDB infected (symptomatic) banana male flowers showed that non-symptomatic flowers produced a greater variety of metabolites compared to symptomatic flowers. The symptomatic flowers produced higher amounts of alpha-pinene compared to non-symptomatic flowers (Figure 3).

Based on Figure 3, volatile metabolites with higher concentration of volatile metabolites in the symptomatic flowers were alpha-pinene, decane, octane, and tetradecane. While the nonsymptomatic flowers had higher concentrations of beta-pinene, limonene, nonane, ocimene, camphene, and 6-tridecene. The volatile metabolite that was dominant in both conditions was alpha-pinene.

\subsection{Quantitative Analysis of Banana Flower Volatile Metabolites}

Alpha-pinene was selected for quantitative analysis using alpha-pinene standard, since this metabolite had the highest concentrations compared to the other metabolites. The results showed that the concentration of alpha-pinene in the female flowers increased from the first stage to the third stage (Table 2). The concentration of alpha-pinene in symptomatic flowers was higher compared to non-symptomatic flowers. This result was relevant to the previous qualitative analysis which showed that the area in the chromatogram of the last stage of inflorescence was larger than the first stage. Alpha-pinene was used for further analysis on insect preference tests.

\subsection{Insect Preference for Alpha-Pinene}

Insect preferences using alpha-pinene standard were generally very different compared to controls for each insect tested. $R$. bhutanensis preference for alpha-pinene (Figure 4a) showed significant differences between treatments and control based on multivariate statistical analysis $(p<0.001$, $\left.F_{(1.5)}=12.539\right)$. Thus there was a significant difference between treatments and control. Further analysis by Duncan test showed that the 2nd treatment (volume $20 \mu \mathrm{l}$ ) was very different from the other treatments. $R$. bhutanensis had a higher preference for the $20 \mu$ volume compared to the other volumes (10 $\mu \mathrm{l}, 40 \mu \mathrm{l}, 80 \mu \mathrm{l}$, and negative control). This meant that the effective alpha-pinene volume to attract $R$. bhutanensis was $20 \mu l$.

The preference of Drosophila sp. to the alpha pinene (Figure $4 \mathrm{~b}$ ) based on M. Anova $\mathrm{p}<0,001$ $\mathrm{F}_{(1.5)}=14.497$. Moreover, Duncan test results show that the most different treatment is the second treatment of $20 \mu \mathrm{l}$ volume. The preference of Drosophila to alpha-pinene that the most preferred volume was also $20 \mu \mathrm{l}$, with an average visit of about 24 insects. The insect visit rate at volume $40 \mu \mathrm{l}$ was about 14 insects, while at $10 \mu \mathrm{l}$, and $80 \mu \mathrm{l}$ were about one and five insects respectively.

The preferences of the $M$. domestica on alpha pinen (Figure 4c) differed significantly at $p<0.001$, $\mathrm{F}_{(1.5)}=36.187$. Further analysis by Duncan test revealed that $M$. domestica preference for alpha-pinene was highest at $20 \mu \mathrm{l}$ volume with only about 15 insects, while for volumes 10,40 , and $80 \mu$ the number of insects that came to visit were only about 2-5 insects. Even though all three types of insects were most attracted to $20 \mu \mathrm{l}$ of alpha-pinene, the numbers of insects that came to visit were different. Drosophila sp. had the highest visiting rate, about 24 insects, which was equivalent to $80 \%$ of the total number of insects in the olfactometer, while $50 \%$ of $M$. domestica and only $46 \%$ of $R$. bhutanensis in the olfactometer chose to visit the arm containing alpha-pinene. 
a

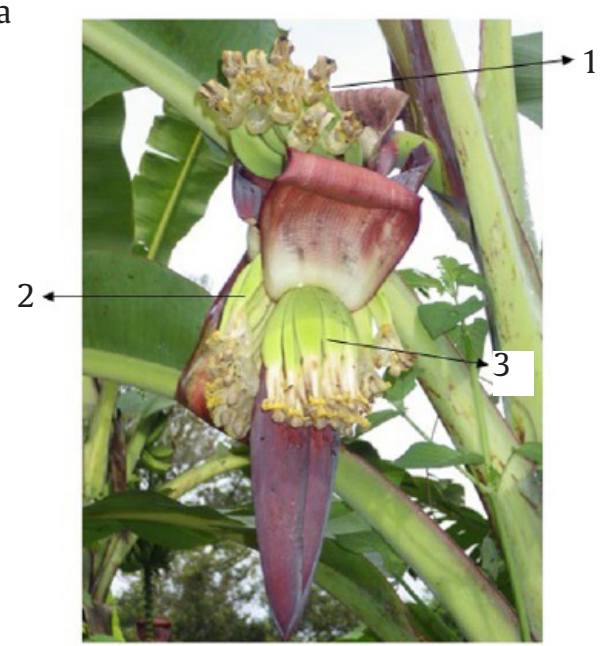

$\mathrm{b}$

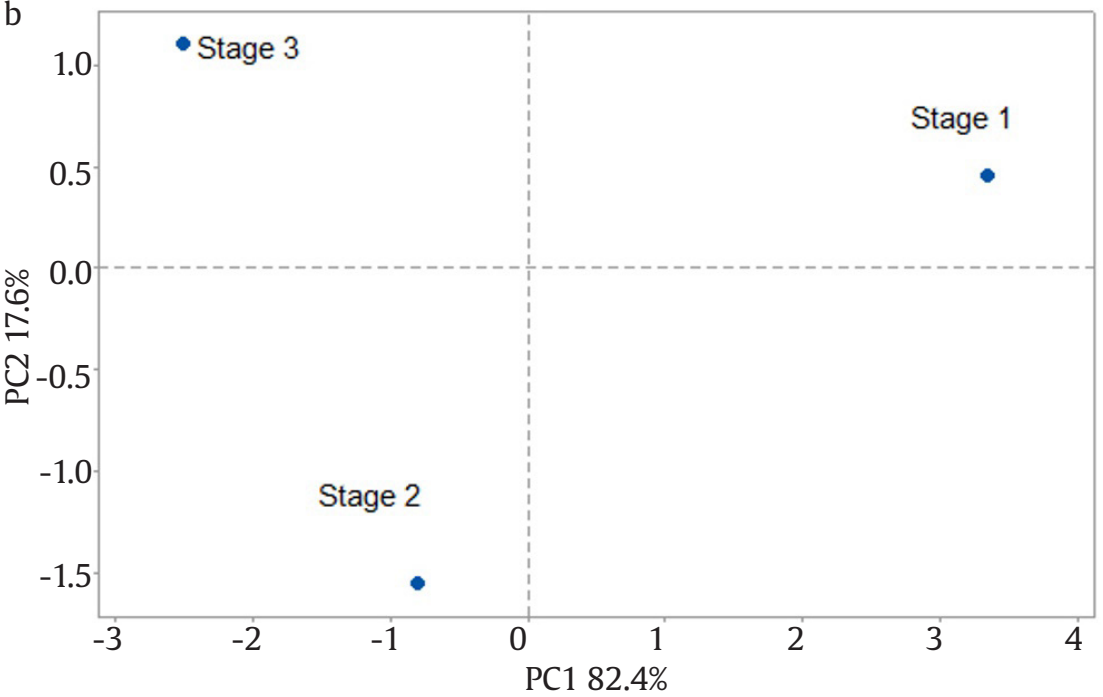

C

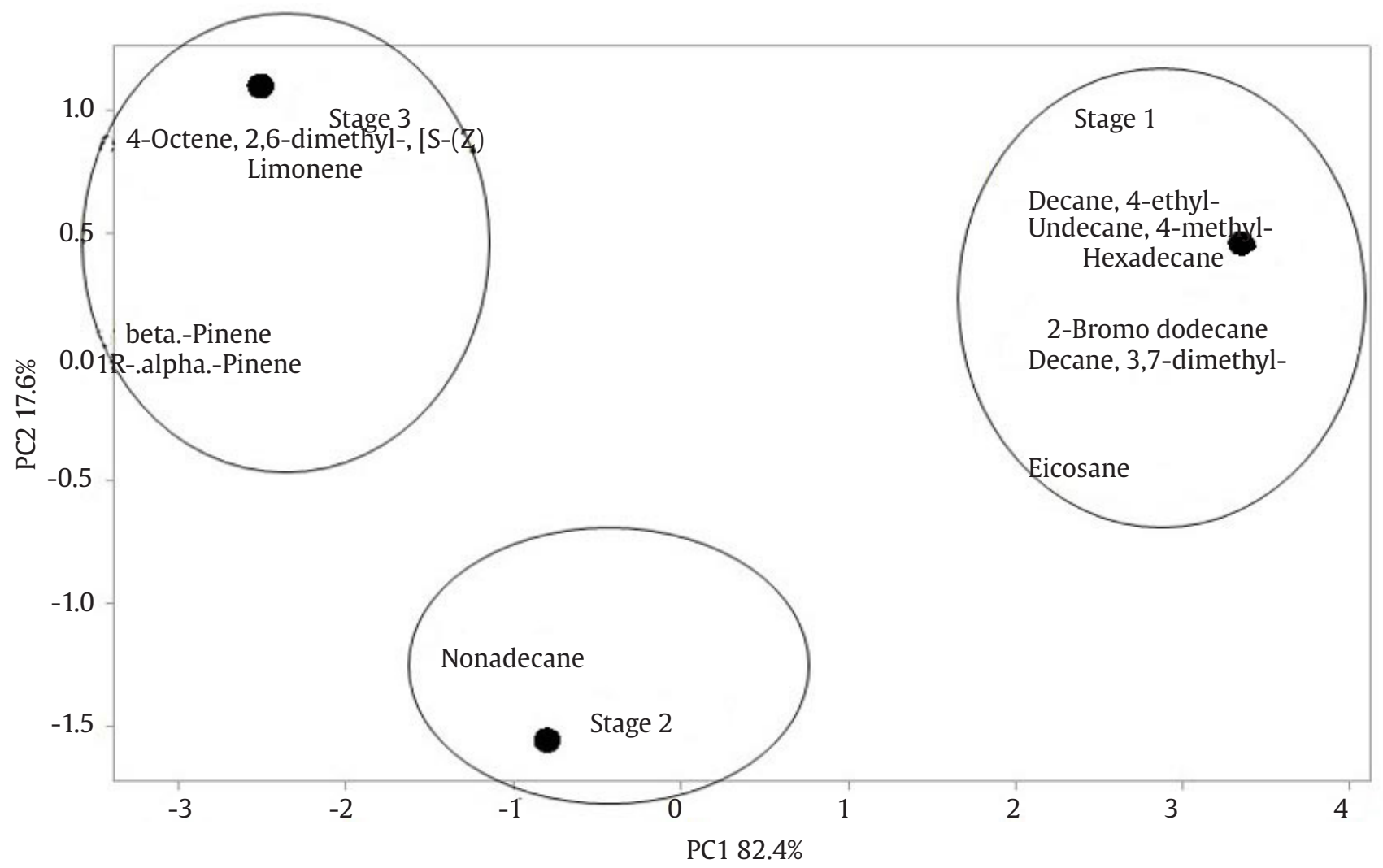

Figure 2. (a) Female flower development, 1 (stage1), 2 (stage 2), 3 (stage 3) which consist of three rows of flowers (top left), (b) PCA analysis of volatile metabolites of banana flower developmental stage, $n=3$ (top right), (c) composition of volatile metabolites at each stage of banana female flower development (bottom)

\section{Discussion}

This study showed that the profiles of volatile metabolites in banana flowers were dominated by monoterpene terpenoids. The differences in the dominant types of volatile metabolites at each stage of the inflorescence were thought to be due to the process of differentiation so that at each stage of flower development produce different types of metabolites. This study was in line with the results of Schmitzer et al. (2009) that showed that each stage of the inflorescence of Rosa $x$ hybrid L. contained different 


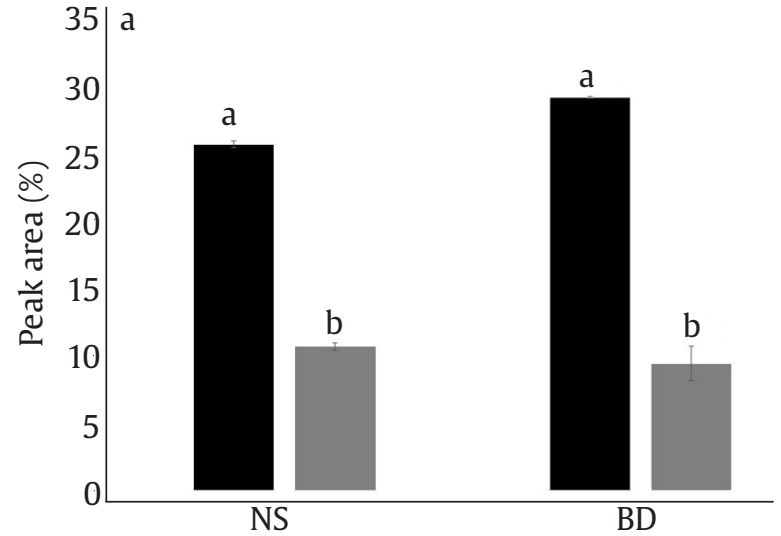

The type of volatile metabolite

Alpha.-Pinene

Beta.-Pinene

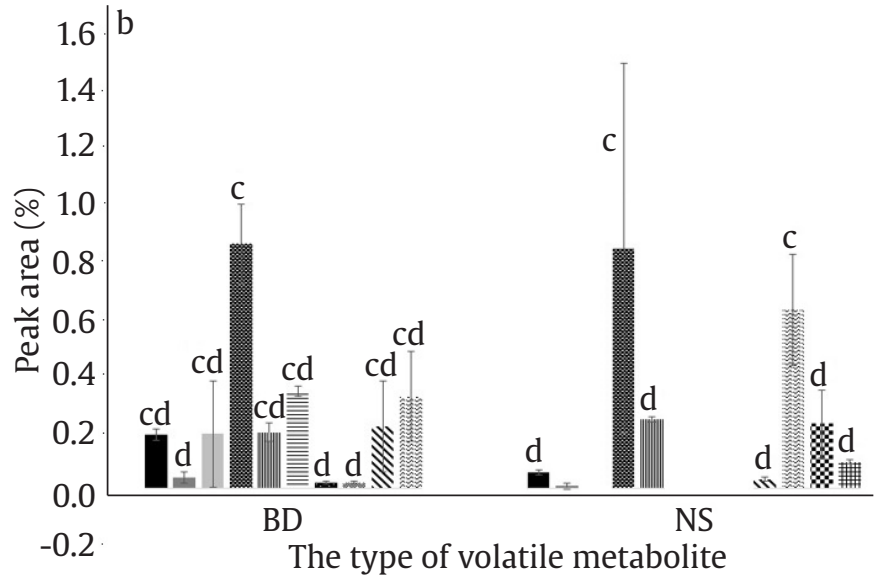

- Decane, 3,7-dimethyl- Decane, 3,8-dimethyl-

Eicosane Limonene

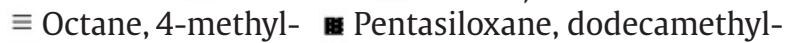

Santolina triene $心$ Tetradecane Undecane, 4-methyl

$\boldsymbol{s}$ Hexadecane \#Ocimene

Figure 3. Comparison of volatile compounds from BDB (BD) infected and non-symptomatic (NS) flowers ( $n=3)$. (a) Comparison of the dominant volatile metabolites alpha-pinene and beta-pinene, (b) comparison of minor volatile metabolites

Table 2. The concentration of alpha-pinene of banana flower development

\begin{tabular}{lc}
\hline The type of flower & Consentration (ppm) \\
\hline Female flower & \\
NS1-3 & 833.98 \\
NS2-3 & 1134.06 \\
NS3-3 & 1177.94 \\
& \\
BDB symptomatic flower and & \\
asymptomatic flower & \\
NS (Asymptomatic) & 1181.80 \\
BD (BDB symptomatic) & 1490.26 \\
\hline
\end{tabular}

a

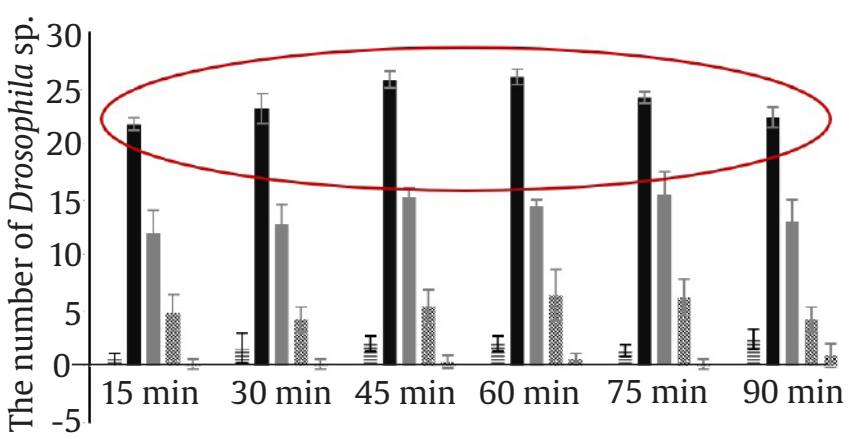

The observation peroid

$\equiv 10 \mu \mathrm{l} \quad$ - $20 \mu \mathrm{l} \quad$ - $40 \mu \mathrm{l} \quad$ \$ $80 \mu \mathrm{l} \quad$ : Control

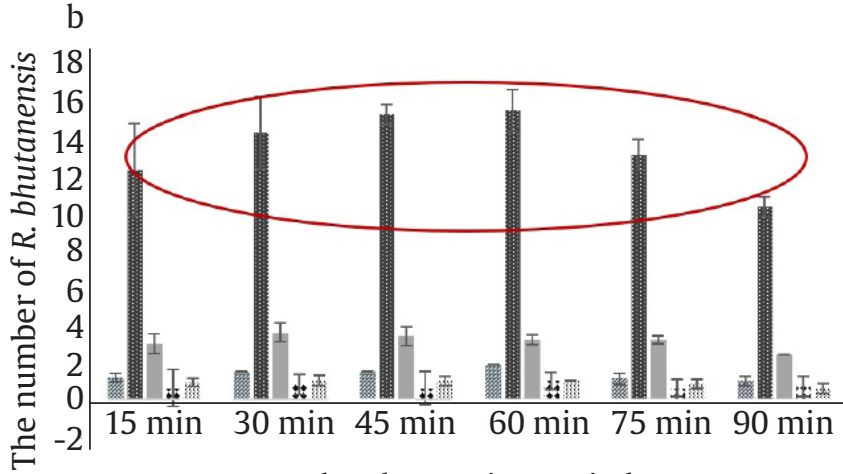

The observation period

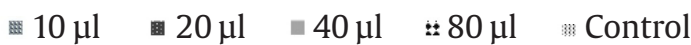

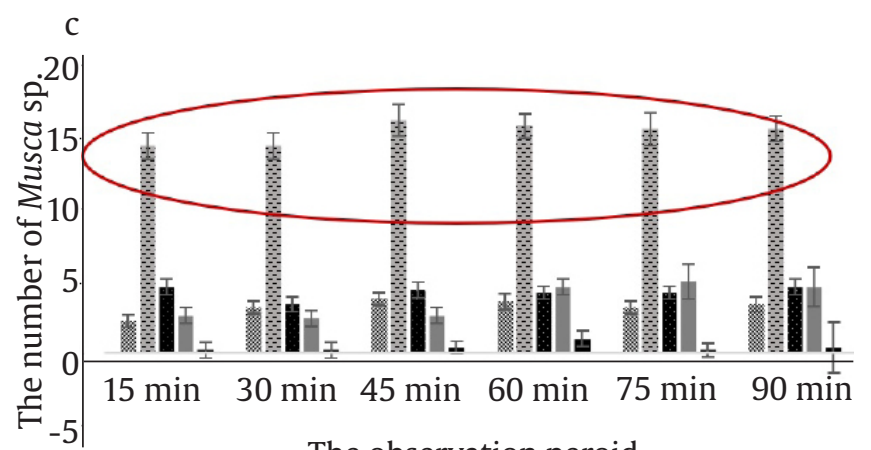

The observation peroid

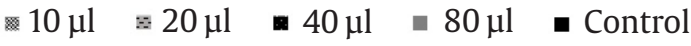

Figure 4. (a) Preference of insects Drosophila sp., (b) R. bhutanensis, (c) Musca sp., for the metabolite alpha-pinene, $\mathrm{N}=30$, 5 replications 
types of metabolites as well. Li et al. (2016) also found that the alpha-pinene content in the inflorescence of Luculia pinceana gradually increased from stage one to stage four. Schade et al. (2001) reported that levels of volatile metabolite at the bud stage to the open flowering phase increased. In contrast Robertson (1995) found that the monoterpene (Limonen) level in Raspberry flowers decreased with flower maturation. Kotze et al. (2010) reported that monoterpene in the Acacia cyclops flower is highest in the early green buds and then gradually decreases in the bloom floral and senescing stage.

Comparison of alpha-pinene content in Figure 3 showed that symptomatic flowers produced higher alpha-pinene than non-symptomatic ones. This was suspected to be triggered by BDB infestation as reported by Nagegowda (2010) and Vranova et al. (2012) terpenoid biosynthesis could be induced by the feeding activity of herbivorous insects, infection by pathogens and abiotic stressors. An increase in the number of terpenoids as a response to abiotic stress was due to increased transcriptional activity of specific genes in terpenoid biosynthesis (Tholl 2006). Pathogenic attacks also caused metabolite and transcriptional changes in Medicago sativa (Suzuki et al. 2005). When Sales et al. (2017) compared alpha-pinene content of the flowers and leaves of Callistemon viminalis, the flowers contained 21.48\% while the leaves only contained about $10.28 \%$.

Alpha-pinene acted as an attractant for $R$. bhutanensis, Drosophila sp., Musca domestica. This was evidenced by the level of preference of these three insects for $20 \mu \mathrm{l}$ volume of alpha-pinene. Erbilgin et al. (2003) reported that alpha-pinene combined with pheromones was highly attractive to the Coleoptera Ips pini (Scolytidae). Anggraeni et al. (2013) reported that oil palm flowers (Elaeis guineensis Jacq) emitted the sesquiterpenes estragol and farnesol that greatly affected insect visitation rates of Thrips hawaiiensis and Elaeidobius kamerunicus. Flowers of Luculia vinceana released the monoterpenes santolina triene, alpha-pinene, limonene, 3-carene, (Z)verbenole, ocimene and $\alpha$-champolenal ( $\mathrm{Li}$ et al. 2016). Limonene is an attractant for D. melanogaster (Dweck et al. 2013). Gerofotis et al. (2013) reported that alpha-pinene can increase the mating success in both male and female Bactrocera sp.

\section{Conclusion}

The dominant volatile metabolite type in the female inflorescence stage was different according to the stage of flower development, although there were some volatile compounds that were always present at each stage with different concentrations. Comparison of metabolites in symptomatic flowers for BDB infection with non-symptomatic ones indicated that alpha-pinene was the most dominant metabolite and quantitatively the production of alpha-pinene was higher in BDB symptomatic flowers compared to non-symptomatic ones. Alpha-pinene was thought to act as an attractant for insect vectors carrying BDB in banana plants, as evidenced by the level of preferences of Drosophila sp., R. bhutanensis, and Musca sp. for alpha-pinene were significantly higher than for the control. This research is a preliminary study for the formulation of BDB insect vector attractant using alpha-pinene as the main ingredient in an effort to control the spread of blood diseases in banana plants.

\section{Acknowledgements}

The authors would like to express their gratitude to the Tropical Fruit Research Institute for permitting the use of the experimental station in Subang for sample collection, and staff of the Flavour Laboratory at the Balai Besar Padi for their assistance and discussion in the analysis of GC-MS. This research was funded by the Indonesian Ministry of Research and Higher Education, program of International Research Collaboration and Scientific Publication (KLN) 2016.

\section{References}

Anggraeni T et al. 2013. Resources partitioning and different foraging behavior is the basis for the coexistence of Thrips hawaiiensis (Thysanoptera: Tripidae) and Elaeidobius kamerunicus (Coleoptera: Curculionidae) on oil palm (Elaeis guineensis Jacq) flower. Journal of Entomology and Nematology 5:59-63.

Borghi M, Fernie AR. 2017. Floral metabolism of sugar and amino acids: implications for pollinators' preferences and seed and fruit set. Plant Physiology 175:15101524.

Bruce TJA et al. 2005. Insect host location: a volatile situation. Trends in Plant Science 10:1-6. 
Dweck HKM et al. 2013. Olfactory preference for egg laying on Citrus substrates in Drosophila. Current Biology 23:2472-2480.

Eden-Green SJ. 1994. Banana blood disease. Musa Disease Fact Sheet No. 3. In: International Network for the Improvement of Banana and Plantain(INIBAP), Montpellier: Department for International Development. pp. 2.

Erbilgin $\mathrm{N}$ et al. 2003. A blend of ethanol and (-)- $\alpha$-pinene were highly attractive to native siricid woodwasps (siricidae, siricinae) infesting conifers of the sierra nevada and the allegheny mountains. J Chem Ecol 43:172-179.

Gerofotis CD et al. 2013. Aromatized to find mates: $\alpha$-pinene aroma boosts the mating success of adult olive fruit flies. PLOS ONE 8:1-8.

Hermanto $C$ et al. 2012. Cropping system approach in the management of major diseases to increase the livelihoods of smaller banana farmes. In: Presented International Banana Symposium: Kaohsiung. pp. 1922.

Junker RR, Bluthgen N. 2010. Floral scents repel facultative flower visitors, but attract obligate ones. Ann Bot 105:777-782.

Kogel WJD et al. 1999. Y-Tube olfactometer to determine the attractiveness of plant volatiles to western flower thrips. Proc Exper and Appl Entomolol 10:131-135.

Kotze JM et al. 2010. Volatiles associated with different flower stages and leaves of Acacia cyclops and their potential role as host attractants for Dasineura dielsi (Diptera: Cecidomyiidae). South African Journal of Botany 76:701-709.

Kustiati et al. 2016. Monitoring permethring and imidacloprid resistence in Indonesia house fly Musca domestica L. (Diptera: Muscidae). Journal of Entomology 13:40-47.

Li Y et al. 2016. Volatile organic compounds emissions from Luculia pinceana flower and its changes at different stages of flower development. Molecules 21:1-10.

Mairawita et al. 2012. Potensi serangga pengunjung bunga sebagai vektor penyakit darah bakteri (Ralstonia solanacearum Phylotipe IV ) pada pisang di Sumatera Barat. J Entomol Indonesia 9:38-47.

Nagegowda DA. 2010. Plant volatile terpenoid metabolism: biosynthetic genes, transcriptional regulation and subcellular compartmentation. FEBS Letters 584:2965-2973.
Pischerky E, Gershenzon J. 2002. The formation and function of plant volatiles: perfumes for pollinator attraction and defense. Curr Opin Plant Biol 5:237-243.

Robertson GW et al. 1995. Changesin the chemical composition of volatiles released by the flowers and fruits of the red raspberry (Rubus idaeus) cultivar glen prosen. Phytochemistry 38:1175-1179.

Rodriguez-campos J et al. 2012. Effect of fermentation time and drying temperature on volatile compounds in cocoa. Food Chem 132:277-288.

Sahetapi B. 2013. Peranan beberapa jenis serangga sebagai vektor penyakit darah pada tanaman pisang. [Disertasi]. Bogor, Indonesia: Institut Pertanian Bogor.

Sales TA et al. 2017. Essential oils from the leaves and flowers of Callistemon viminalis: chemical characterization and evaluation of the insecticide and antifungal activities. American Journal of Plant Sciences 8:25162529.

Schade F et al. 2001. Fragrance volatiles of developing and senescing carnation flowers. Phytochemistry 56:703710.

Schmitzer V et al. 2009. Changes in the phenolic concentration during flower development of rose 'KORcrisett'. J Amer Soc Hort Sci 134:491-496.

Suharjo R et al. 2006. Potensi Erionota thrax sebagai agen penyebar patogen penyebab penyakit layu bakteri pada tanaman pisang (Blood Disease Bacterium). J HPT Trop 6:100-106.

Supriadi 2005. Present status of blood disease in Indonesia. In: Allen C, Prior P, Hayward AC(Eds.). Bacterial Wilt Disease and the Ralstonia solanacearum species complex. St Paul: Minnesota. pp. 395-404.

Suzuki H et al. 2005. Methyl jasmonate and yeast elicitor induce differential transcriptional and metabolic reprogramming in cell suspension cultures of the model legume Medicago runcatula. Planta 220:696-707.

Tholl D. 2006. Terpene synthases and the regulation, diversity and biological roles of terpene metabolism. Curr Opin Plant Biol 9:297-304.

Vranova E et al. 2012. Structure and dynamics of the isoprenoid pathway network. Mol Plant 5:318-333. 